\title{
Sugar industrialization and distress selling of livestock among the Bodi pastoralists in Ethiopia's lower Omo valley
}

\author{
Fana Gebresenbet
}

\begin{abstract}
This article, based on long-term fieldwork, argues that the Bodi, a small agro-pastoral community in Ethiopia's lower Omo Valley, are experiencing distress selling of livestock and are undergoing collective impoverishment. These processes are a result of the rapid comprehensive transformations unfolding in the valley, which are themselves a product of the state's aggressive resource extraction interests. These interests mainly relate to the building of the Gilgel Gibe III dam on the Omo River and the establishment of large-scale sugar estates. Increased insecurity in the valley followed these interventions. When combined, these changes resulted in the deterioration of the food security and livelihood situations of the Bodi, and the community attempted to cope by selling animals from their herds. Hence, the main reasons for market engagement relate to (1) coping with hunger, (2) coping with a high incidence of animal diseases and (3) coping with high rates of imprisonment of men. The Bodi also engage in three constrained livelihood alternatives: rain-fed farming, irrigated farming and wage employment. This article recommends that resolving the Bodi's erosion of livelihoods necessitates addressing insecurity and the related socio-political outcomes, which lie at the heart of the Bodi's dwindling livelihood situation and impoverishment.
\end{abstract}

Keywords: South Omo, Sugar industrialisation, Gilgel Gibe III dam, Konso, State resource extraction

\section{Introduction}

Pastoralists are often wrongly perceived by governments and development practitioners as market averse (Schareika 2018). Indeed, the pastoral production system itself is at times viewed as a problem to be eradicated (Schlee 2010), leading to policies and development interventions centred on sedentarization and changing land uses. Moreover, many interventions aim to increase commercial off-take of livestock from pastoralist communities (Barrett, Bellemare and Osterloh 2006; Schareika 2018; Schlee 2010: Vincent et al. 2010; for a South Omo-specific, work see Bogale et al. 2014). While supporting and promoting a viable pastoral production system is one key strategy to increase the extent of pastoralists' market engagement, state action is often disproportionately geared towards the supply of physical

Correspondence: fana.g@ipss-addis.org

Institute for Peace and Security Studies, Addis Ababa University, Addis Ababa, Ethiopia

Springer Open infrastructure and market information (Barrett, Bellemare and Osterloh 2006).

The economic efficiency of mobile pastoralism in arid and semi-arid areas has been well recognized by scholars (cf. Behnke and Kerven 2013), including that pastoralists, far from being self-sufficient, need to engage in market exchanges. Studies on the livestock marketing behaviours of pastoralists in the Horn of Africa disproportionately focus on territories already linked with national and regional markets, mainly Borana, Somali and Afar territories (Aklilu and Catley 2014; Aklilu and Catley 2010a; Aklilu and Catley 2010b; Aklilu and Catley 2010c; Eid 2014). By focusing instead on the Bodi agro-pastoral group located in Ethiopia's lower Omo valley (an area that opened for market engagement only in the late 2000s), this article presents a case of increasing marketization of livestock not as a response to 'development' but by conditions of high insecurity accompanying

(c) The Author(s). 2021 Open Access This article is licensed under a Creative Commons Attribution 4.0 International License, which permits use, sharing, adaptation, distribution and reproduction in any medium or format, as long as you give appropriate credit to the original author(s) and the source, provide a link to the Creative Commons licence, and indicate if changes were made. The images or other third party material in this article are included in the article's Creative Commons licence, unless indicated otherwise in a credit line to the material. If material is not included in the article's Creative Commons licence and your intended use is not permitted by statutory regulation or exceeds the permitted use, you will need to obtain permission directly from the copyright holder. To view a copy of this licence, visit http://creativecommons.org/licenses/by/4.0/. 
aggressive state interventions. The literature on land investments and large-scale state-driven development projects in Africa mainly focuses on strains on food security and livelihoods (Batterbury and Ndi 2018; Davis et al. 2014; Matondi et al. 2011). This article takes a new angle by paying special attention to Bodi's emerging livestock marketing behaviour due to increasing insecurity associated with state extraction interests.

The all-too-common misperception of pastoralists' livestock market engagement has informed development practice over the past decade in the lower Omo valley. The government aggressively intervened in the valley with the objective of advancing the Ethiopian developmental state project. These interventions were based on the assumption, as stated by the late Prime Minister Meles Zenawi (2011), that the valley's pastoral groups were 'backward' and in 'need of saving' from poverty and disaster. He asserted his government's commitment to make South Omo 'an example of rapid development'. The lower Omo valley then became a scene for unfolding transformative changes, undergirded by the government's aggressive resource extraction interests. The changes came through the building of the Gilgel Gibe III dam (often called Gibe III) on the Omo River and the establishment of large-scale sugar estates.

These infrastructure and economic investments were reportedly intended to provide the conditions for a 'stable' and 'secure' life for local agro-pastoral communities. In this developmental effort, Meles Zenawi (2011) stated that local inhabitants would be the first beneficiaries and that 'there will be support for the pastoralists to combine agriculture with modern cattle herding'. This goal was planned to be operationalized through, among other things, the creation of massive market opportunities (thanks to the hundreds of thousands of jobs that would be created by the sugar estates) and the expected increase in livestock market prices (Southern Ethiopia Peoples' Democratic Movement (SEPDM) 2010).

The reality on the ground could not have been more different. A cascade of bad decisions followed in the decade after the commencement of sugar industrialization. The anthropologist David Turton captured it aptly when he concluded that the river basin development in the Omo Valley has become such a text-book example of "how not to do it" (forthcoming: 377, italics in original) and that it was an example of 'breaking every rule in the book' (Ibid.: 375). As argued in this article, 'development' in practice led to tension and insecurity, triggering Bodi's distress selling of livestock resulting in their impoverishment.

This article is in eight sections. Following the introduction, the second part describes the study area, South Omo, and more specifically Salamago district and its inhabitants. The third outlines the methods, and the fourth provides the political context and major features of development interventions in South Omo. The fifth shows that, for the local community, development brought few gains and many losses, primarily in regard to security. The sixth part details the implications of insecurity on the livestock marketing behaviour of the local community. The next section argues that the trend of distress sales of cattle leads to collective impoverishment. The concluding section outlines policy recommendations.

\section{Study area: Ecology and people of the lower Omo valley}

The lower Omo valley constitutes Ethiopia's southwestern frontier territory, bordering Kenya to the south and South Sudan to the west (see Fig. 1 below). The Omo River, which terminates at Lake Turkana, is the valley's most defining geographic feature. The zone close to the river and lake is arid and semi-arid lowlands and cannot support rain-fed farming. Hence, mobile pastoralism is the most viable production system which can exploit the spatially and temporally erratic natural resources. The riverbanks, which often flood in August, are critical sites of food production, with all groups bordering the Omo River practising flood-retreat agriculture. Thus, the diet of communities living in the valley comes from a combination of flood-retreat agriculture and livestock rearing. Groups bordering the mountain ranges facing the valley, primarily the Bodi and Mursi, have an additional food source, as they are able to practise rain-fed farming in the mid-altitude areas (see Fukui 2001).

South Omo Zone, where the fieldwork for this article took place, lies to the east of the river (except Nyangatom and parts of Dassanech districts) and is the most ethnically diverse administration within Ethiopia. The administrative zone is home to sixteen indigenous ethnic groups. The numerical majority, Aari and Maale ethnic groups, accounting for two-thirds of the Zone's population, are agrarian. ${ }^{1}$ The remaining ethnic groups are agropastoralists, residing in six districts. Sugar industrialization works are restricted to Salamago and Nyangatom districts, with activities having started much earlier in the former. Four ethnic groups are indigenous to Salamago district, i.e. the agro-pastoralist Bodi and Mursi, the fishing community of the Kwegu and the agrarian Dime. This article is based on the experiences of the Bodi.

While the economic life of the Bodi used to depend equally on flood-retreat agriculture along the Omo River, rain-fed farming in mid-altitude areas and

\footnotetext{
${ }^{1}$ South Omo Zone's population in the 2007 population and housing census was about 600,000 (Central Statistical Agency (CSA) 2008). A much smaller group, the Dime, also exclusively rely on rain-fed farming.
} 


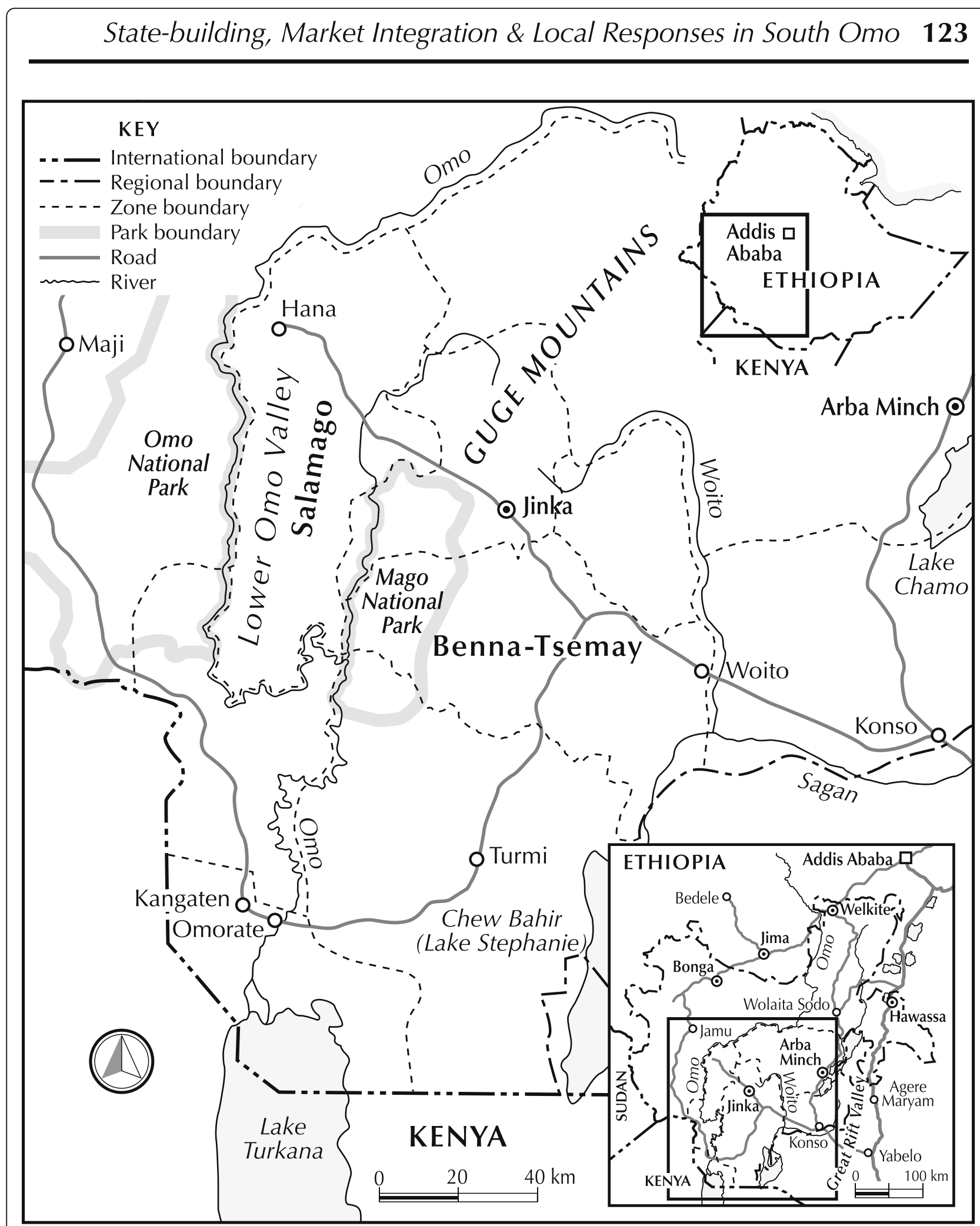

Fig. 1 Map of the South Omo Zone 
livestock keeping in the rangelands, their socio-political life and culture is mainly linked to livestock. Prior to the early 2000s, the local economy was subsistence-oriented with intermittent and limited monetized market engagement. Local livelihoods and economy were only influenced by, and mainly responding to, environmental dynamics and pressures from competing neighbouring pastoral groups. The extent of state and market penetration was very low until the 2010s (see Buffavand 2017). The undeveloped 'state accessible economy' (see Scott 2009), the difficulty of governing and extracting from/ taxing the agro-pastoralist population, and the hot climate of the lowlands (Markakis 2011) contributed to limiting government's interest to intervene in these lowlands. Until the 2000s, the government's main interest in the region was reducing pastoral conflicts. ${ }^{2}$ As a result, there were no serious interventions to improve the welfare, lives or livelihoods of agro-pastoral groups. This lack of investment translated into a dismally low level of socio-economic development in the zone.

Successive Ethiopian governments have viewed agropastoral groups as 'irrational', 'traditional' and 'backward' and being against 'modernity' (see Gabbert 2021: 9-13). Perceived as simply 'surviving' through 'basic' skills, agro-pastoralists have been recently characterized as lazy by the federal government (Government Communication Affairs Office 2015). Pastoralists' complex, rich environmental and resource management knowledge and skills (see Abbink et al. 2014) are often conveniently glossed over in government development discourse and practice. Government discourse has specifically criticized the Bodi for not making efficient use of local natural resources and for being 'hot-tempered' 'warmongers' who fight at the slightest opportunity. ${ }^{3}$

The Ethiopian government viewed South Omo (an administrative zone) as a resource frontier, an area 'empty but full,' i.e. empty of social relations, but full of potential for economic invigoration (Bridge 2001: 2161). This justified the deployment of aggressive modernist visions (Mosley and Watson 2016) in the name of creating stable conditions for and improving the lives of agropastoralists (Zenawi 2011) and reducing pastoral conflicts. ${ }^{4}$ The statist view of development was invariably conditioned on sedentarization of pastoralists and their adoption of irrigated farming as a primary livelihood (Stevenson and Buffavand 2018; Woldemariam and Gebresenbet 2014). The creation of a large cattle market in South

\footnotetext{
${ }^{2}$ Interview: Expert in Zone's Security and Administration Office, October 2017, Jinka, South Omo.

${ }^{3}$ Interview: Senior Expert, Zone Security and Administration Office, October 2017 and August 2018, Jinka, South Omo.

${ }^{4}$ Interview: Senior Experts at the Zone's Administrator's Office and the Zone's Security and Administration Office, October 2017, Jinka, South Omo.
}

Omo and anticipated increase in livestock prices was also part of the modernization plan (SEPDM 2010).

\section{Methods}

This article is based on extensive qualitative fieldwork in South Omo since early 2013. Over the past 7 years, I did fieldwork for more than 100 days mainly in Jinka and Salamago. During this period, I conducted interviews with more than 150 individuals. Interviews have been conducted with local government officials and experts based at zone and district governments, staff of the Ethiopian Sugar Corporation (ESC) and officials of the regional government. In addition, individual interviews, informal conversations and focus group discussions were held with individuals (mainly older men, but also engaging women in FGDs) drawn from different sections of the Bodi. Relevant documents and legal texts were collected and reviewed. Author observation during the numerous field trips informed the analysis for this article.

This article's central argument draws on fieldwork carried out in Salamago district of South Omo Zone in August 2018 with a focus on the livestock marketing behaviour of the Bodi. During this field visit, I conducted eight individual interviews with experts based at the zone and district levels, and Bodi men; held focus group discussions with another 20 individuals (14 men (8 young and 6 old) and 6 women); and engaged in numerous informal conversations with town residents and those working at the sugar corporation. Emerging from this fieldwork was the impact of mega-development projects on livestock marketing behaviour, discussed in the "Implications of persistent insecurity on livestock marketing" section. The next section details the mega-development projects affecting various aspects of life in the lower Omo valley.

\section{Mirage of development in South Omo}

On 25 January 2011, in a speech delivered at the 13th Pastoralist Day celebration in Jinka, the capital of South Omo Zone, Ethiopia's late Prime Minister Meles Zenawi announced his government's plan to 'modernize' lower Omo valley's pastoral lowlands. He stressed that his government would transform the valley from an example of backwardness to one of rapid development. He insisted that pastoralists wanted a 'stable, improved life', which he stressed would be delivered by state-managed development (for a critique, see Turton 2021). This epoch, from the government's perspective, was to be the 'dawn of development' for the valley. In practice, it was only a mirage.

'Development' in these lowlands started with the building of the Gibe III to the north of the lower Omo valley and continued with sugar estates and mills and a sedentarization scheme (see Kefale and Gebresenbet 2014; Woldemariam and Gebresenbet 2014). The construction of the Gibe III dam (between 2006 and 2015) 
opened up the lower Omo resource frontier for economic integration and irrigated agriculture (Stevenson 2018). The crop to be grown in South Omo's vast 'unused' lowlands was sugarcane, linked with the establishment of sugar mills. By the early 2010s, developers planned to plant up to 175,000 ha of sugarcane to supply five factories. In addition to creating job opportunities for at least 400,000 Ethiopians, these plantations and mills were expected to generate foreign currency and electricity (for details see Ministry of Finance and Economic Development (MoFED) 2010; Woldemariam and Gebresenbet 2014). However, by 2016, sugarcane covered only 10,000 ha and an additional 13,000 ha was cleared (Kamski 2016). By late 2018, only one factory was operational (officially as of 14 October 2018). ${ }^{5}$

Alongside sugar industrialization activities, the government commenced a comprehensive scheme of modernizing the Bodi via a 'voluntary villagization' scheme (Gebresenbet 2021). This modernization project was premised on the need to sedentarize the pastoral community in planned villages where the government would deliver public services, such as schools, clinics, veterinary clinics, grinding mills, potable water, kebele (lowest administrative unit) and police stations. As an incentive to relocate, the government provided free food for about half a year to lure people into the newly established villages (for details, see Gebresenbet 2021; Stevenson and Buffavand 2018; Woldemariam and Gebresenbet 2014).

The government also promoted settled farming in South Omo with the 'distribution' of land and the promise of access to irrigation (from the facilities of the sugar estates). In 2013, the plan was to let each Bodi household farm staple crops (mainly maize) on a hectare of land. By 2016, the government determined that recipient Bodi households were not making productive use of the land, and forced the relocated community to collectivize their plots into becoming outgrower sugarcane communal farmers by contributing 0.75 ha of the land allocated per settled household. ${ }^{6}$ This left 0.25 ha for subsistence farming of staples. In July 2016, about a third (512) of the 1430 Bodi households who joined the new villages collectivized their land to supply sugarcane to the factories. ${ }^{7}$

However, irrigation water only reached the plots closest to the main canals and the fully cleared landscape (i.e. absence of shades provided by trees) exposed the

\footnotetext{
${ }^{5}$ See https://www.slideshare.net/meresaf/ethiopian-sugar-industryprofile-166554323

${ }^{6}$ Interview: Experts, Bureau of Agriculture and Pastoralist Affairs Office, Hana town, Salamago district, October 2017. See also Buffavand 2021.

${ }^{7}$ Interview: Experts, Bureau of Agriculture and Pastoralist Affairs Office, Hana town, Salamago district, October 2017.
}

Bodi to unbearable farming conditions (Stevenson and Buffavand 2018: 120). As the sugar factories were not running years after the planned commissioning day, the Bodi have yet to benefit from the contract farming scheme. Neither are they allowed to reclaim the land they collectivized to grow maize or other staples. Despite an initial spell of intense activity, failure of the sugar development projects led to a decline in pushes to sedentarize the Bodi half a decade later (Gebresenbet 2021).

The government's modernization plan also constituted encouraging the Bodi to link up with the modern economy. A limited proportion of the jobs created in the plantations and related infrastructure works, especially unskilled jobs on the farms, such as security guards, went to the Bodi. The local economy also became increasingly monetized, leading to the opening of the area's first branch of a financial institution, the Commercial Bank of Ethiopia, in 2018. ${ }^{8}$ In addition, the government established a livestock market centre-i.e. the physical infrastructure within which legal trade should happen-in Hana, the district's main town, intending to garner better prices for the Bodi and to generate government revenue from taxing the trade. ${ }^{9}$ The sale of animals would also supply meat to the labour force $^{10}$ and the towns' growing population. Moreover, there were plans to link local livestock production with the sugar industries, by using molasses, a byproduct of sugar mills, as animal feed (SEPDM 2010). As discerned from the above, the government hoped to create various synergies between sugarcane and livestock production.

The early enthusiasm of experts and officials to transform the lives of the Bodi seen early in the production scheme (during fieldwork in 2013) dampened in due course. The lands newly cleared for agriculture and homesteads in 2013 were covered with regenerating grasses and bushes by 2018. This personal observation and many accounts from the local community attest that this modernizing project was not followed through and failed to bear fruit. The promise and enthusiasm of experts and officials to 'introduce' pastoralists to modernity were dashed in only half a decade.

\footnotetext{
${ }^{8}$ Interview: Experts, Bureau of Agriculture and Pastoralist Affairs Office, Hana town, Salamago district, October 2017.

${ }^{9}$ According to the ESC (2018), by mid-2017, some 80,000 jobs were created in sugar development activities directly and another 50,000 indirectly. These jobs are in both Salamago and Nyangatom districts where sugar development is occurring. As the activities are longstanding and more advanced in the former, it is likely that most of these jobs are in Salamago.

${ }^{10}$ See for example https://www.fanabc.com/english/ethiopia-beginssugar-stocking-to-avoid-supply-shortages/ (last accessed on 19 August 2020).
} 


\section{Development in practice: Little gains, deepening insecurity in Salamago}

The development interventions in South Omo miserably failed. Ethiopia continues to face sugar shortages, let alone generate the hundreds of millions of dollars originally forecasted. ${ }^{11}$ The negative consequences of the interventions have been severely felt by the Bodi. Following the filling of the Gibe III dam reservoir in 2015, the agro-pastoral communities in the Omo valley, including the Bodi, could not practise flood-retreat agriculture. Moreover, due to the tense situation and fear conflict with the Konso, ${ }^{12}$ the Bodi can no longer productively practise rain-fed agriculture in mid-altitude areas where Konso had been resettled by the regional government (discussed below). This translates into the Bodi losing two streams of their food production-recession and rain-fed farming-and becoming increasingly food insecure. ${ }^{13}$ Thus, the Bodi today rely greatly on markets to exchange livestock for grain. ${ }^{14}$

Of the six pastoral districts of the zone, Salamago had some of the lowest pastoral conflicts and other forms of violence before the commencement of 'development' interventions (Markakis 2011). ${ }^{15}$ As an expert in the district government stated, civil servants in Hana, the district capital, were 'more afraid of wild animals attacking them in the long trek/drive to Jinka', than attacks by the Bodi or the Mursi a decade ago. The Bodi and Mursi were friendly to outsiders and did not ambush vehicles. The notoriously poorly maintained road from Hana to Jinka (travelling the $100 \mathrm{~km}$ took over a day) was improved in the mid-2000s to facilitate the resettlement of the landless and food-insecure Konso community from about $200 \mathrm{~km}$ to the east (Asfaw 2005). Another round of road improvements was undertaken in the early $2010 \mathrm{~s}$ to facilitate activities related to sugar industrialization. Despite improvements in the physical condition of the road, civil servants with long experience in the zone and district stress that travel in earlier times felt safer.

The increasing traffic and speed of vehicles was a major trigger for violent reactions and increasing insecurity. Many trucks and 4WD vehicles now frequent the roads on a daily basis, and regular car accidents have led to revenge attacks by the local community. For example, after

\footnotetext{
${ }^{11}$ The regional government settled hundreds of food-insecure households from the Konso agrarian ethnic group in the mid-altitude areas in 2004 (Asfaw 2005). Conflict between the Bodi and Konso became common-place in the early 2010s (more on this in coming sections).

${ }^{12}$ Interview: Elders and Administrators, Kangaten, Nyangatom district, August 2018.

${ }^{13}$ Interviews and FGDs with members of the local community, Hana town and village sites, Salamago district, July 2018.

${ }^{14}$ Between 2000 and 2005, only five killings were reported from the woreda, while 29 was reported from Hamer and 171 in Kuraz (Markakis 2011: 340-341).

${ }^{15} \mathrm{https}$ ///www.thereporterethiopia.com/article/south-omo-violenceleaves-12-dead (last accessed on 25 October 2018).
}

a young Bodi man was killed by a truck on 4 December 2017, Bodi men took revenge by attacking vehicles and drivers, killing at least twelve on that day. ${ }^{16}$ Although this example is an unusually high number of revenge killings, the threat and feeling of insecurity while traversing the road is elevated and persistent. Two further examples illustrate the insecurity and fear in the district. First, since approximately mid-2016, the district government imposed a curfew of 10:00 PM in Hana town. All bars and restaurants, mainly serving the sugar sector's labour force, were forced to close. Second, on Saturdays, a market day in Hana, many Bodi pastoralists come to town to sell livestock. This, district government officials argue, is often followed by heavy drinking and a rise in quarrels and conflicts by young men. To prevent this, district administrators now close the market early (around $2 \mathrm{PM}$ ) and the police limit access by the Bodi to the outskirts of the town. In both cases, it is Bodi young men who are viewed as threatening the town's peace.

Such government security considerations and actions did not start only after Bodi attacks on state interests. One of the first government actions before the land clearing and other works started was a 'security campaign', a misnomer often given to actions that end up bringing additional grievances and layers of insecurity in the district. Security campaigns were repeated annually since then. Such campaigns last for weeks and were implemented with the aim of taking individuals suspected of committing various past crimes into police custody. As a result of such campaigns, more than 300 Bodi men ${ }^{17}$ were being held in Jinka prison facility as of mid-2018. ${ }^{18}$ The legal proceedings were not fair, especially as they were in Amharic and as the suspected Bodi men did not get proper representation. The Bodi's interpretation of these campaigns is that they are to pre-empt potential resistance against the sugar development and sedentarization schemes, as well as to stop fighting with the Konso. ${ }^{19}$ The most recent of such campaigns aimed to disarm the Bodi

\footnotetext{
${ }^{16}$ This is not a small number for a community numbering less than 10,000 (see CSA 2008). If half of this population is male, and if out of these the physically capable to mount a violent resistance (age-wise), the 300 imprisoned are from a sub-set of about 2000 in number. Very few individuals were released in 2020 (those with few months left from their sentence periods) to reduce the risk of congestions in prisons amid COVID outbreaks. However, as more prisoners were added in September 2019, the total number of Bodi men in Jinka's prison did not significantly reduce (phone interview, expert in Hana town, September 2020).

${ }^{17}$ Interviews and FGDs with members of the local community, Jinka and Hana towns, July 2018. Lucie Buffavand (2021: 415-417) details the imprisonments which were happening since 2011.

${ }^{18}$ Interviews: Zone Official, Jinka, August 2018; district expert, Hana, July 2018.

${ }^{19}$ Last accessed on 19 August 2020 from https://www.canr.msu.edu/ oturn/Memo_(4.0)_on_violence_in_South__Omo_areas_SNNPRS Ethiopia_(26_October_2019).pdf.
} 
(and the Mursi) in September 2019. The campaign involved destroying property, widespread beatings, and the killing of at least 38 Bodi individuals (including a 10month-old baby) in less than a month. ${ }^{20}$

Tensions and insecurity reigned in the early 2010s due to the dynamics related to the resettlement of the Konso in the previous decade. The Bodi insist that the government promised them (during consultations in the mid2000s, before bringing the Konso) that the settlers would leave for their original villages after 5 years. The government determined 5 years as enough time for them to become food secure. The Bodi's position was, therefore, that the Konso should have returned when this period lapsed. The Konso, however, became very profitable sesame farmers, brought their kin and expanded their land, with no indication from the government of intentions to stop them from settling long term. Initially, the Bodi inflicted more harm on the Konso, until the Konso armed themselves with small arms (from profits made from sesame farming) and defended themselves. Moreover, the government typically sides with the Konso, according to Bodi residents of the area and observers (Buffavand 2017; various interviews).

To summarize, the Bodi reacted violently, mainly to deaths and injuries of community members due to vehicle traffic and to the territorial encroachments of the Konso. Violence begat more violence. In this process, the image of pastoralist groups as violent, irrational and backward was further reified and consolidated, attracting more state action, mainly in the form of police intervention. In this vicious circle, the Bodi are destined to lose, as will be shown in the following pages.

\section{Implications of persistent insecurity on livestock marketing}

The Bodi's market engagement significantly increased over the past decade. This was in line with government expectations and was driven, in part, by the large population increase ${ }^{21}$ and associated rise in demand for meat and other commodities. The Bodi have benefitted from the significant increase in prices brought about mainly by the spike in demand and the government's attempt to limit livestock sales to the established market centre where prices are better. However, the Bodi's livestock marketing behaviour is not a reflection of their intention

\footnotetext{
${ }^{20}$ The district's population tripled during this period (given the job creation estimates provided in footnote 9). On top of this, all of the additional inhabitants buy food from the markets and are likely to have higher levels of meat consumption.

${ }^{21}$ Save for the widespread regional drought of 1980s, during which the Bodi also received food aid (Buffavand 2017; also Interview: Salamago district expert, with long experience, Hana town, July 2017 and 3 August 2018). The current round was special, as the food shortage is mainly a result of state interventions.
}

to modernize by commercializing their production system. Rather, as discussed below, they are engaging in local market processes to cope with increasing tension and persistent insecurity in Salamago. When asked to prioritize their expenses following a cattle sale, Bodi informants unanimously agreed upon maize to abate hunger as the most important purchase. In fact, being able to purchase maize was often the main reason for selling the animal. The shift in livelihood represented by this trend is best captured by the two quotes below:

We had plenty to eat before all this sugar [industrialisation] and road works started. We were a happy people. We did not need to sell cattle [to buy food] in old days. Now we are selling from our herd just to eat. We are being reduced to surviving by buying maize... We are not happy! (FGD-men participant, Bodi elder, Village I site, Salamago, August 2018)

Look at these children [pointing at a group of three children] who are now simply wandering in the town [Hana]. Some are now becoming used to eating leftovers from the restaurants and town residents.... In the past, all of us had enough to feed our children. Now our granaries are empty and we are not sure when we will have a good harvest. We are not certain what our children will eat in the future .... (FGD participant, Bodi women, Hana town, August 2018).

This state of hunger, created by the inability to produce food for the community, is only a recent reality. ${ }^{22}$ The Bodi have enjoyed the geographic accident of being located in an area where, in the past, they could practice both recession and rain-fed agriculture (in addition to livestock rearing) and be largely self-sufficient. The combined impacts of the absence of floods since the filling of the Gibe III dam in 2015 and the inability to maintain rain-fed agriculture due to conflict risks with the Konso (as of the early 2010s) have resulted in severe food insecurity. The Bodi have thus been forced to rely mainly on the market to meet their grain needs for the first time in their history. ${ }^{23}$

Answers regarding the second most important expense fell into two main categories. One was finances related to the imprisonment of men in Jinka, and the other was the maintenance of animal health. The imprisonment of the about 300 Bodi men has put immense pressure on

\footnotetext{
${ }^{22}$ Interview: Salamago district expert, with long experience, Hana town, July 2017 and 3 August 2018.

${ }^{23}$ FGD with women, Hana, 6 August 2018. The period before getting pregnant with another is determined by the fact that a child should be able to run by himself/herself, and reduce the need for care, important in times of conflict, according to one of the FGD participant.
} 
households and the community left behind. The absence of the male labour has reduced the productivity of the limited rain-fed farming (as men do most of heavy manual labour) in addition to reducing the care given to the household herd. This loss for the household is more acute if no son is the right age to take over his father's responsibilities. In addition, a man's wife or wives are, at the very least, compelled to send him money during imprisonment.

Prior to 2016, wives of imprisoned men could sell cattle to travel to Jinka (accompanied by a man from the family) for a 'conjugal visit'. These visits allowed couples to meet the cultural requirement for a wife to give birth every 2.5 to 3 years. Giving birth in strict adherence to this birth cycle gives a woman high status. This is conceived as a way of returning the bridewealth paid for her hand in marriage, as the husband's family stands to benefit from the children. ${ }^{24}$ One FGD participant claimed sadly that the 4 years her husband was imprisoned was 'a waste of her child-bearing period' as her conjugal visits did not lead to any pregnancy. She exclaimed that the years were 'a loss of my years and our animals! ${ }^{25}$

Such visits were expensive, mainly because they were not legal, and required the bribing of prison guards who would take the men out under the pretext of a hospital visit. The expenses involved travel (more than a hundred kilometres), accommodation, meals/subsistence including those of the accompanying man, and money given to the prisoner. Wives and close relatives of the imprisoned reported selling an average of 1.5 to 2 cattle every year that a man was in prison to fund these expenses. ${ }^{26}$ However, other prisoners began to protest the 'special treatment' of Bodi prisoners, leading to the cessation of conjugal visits in 2016. Since then, families sold animals partly to visit as well as send some money to the imprisoned men.

When discussing veterinary care, the Bodi explained that their animals experienced high disease mortality rates after the mid-2010s. Reduction in territory due to insecurity, sugar estates and resettlement schemes means that herders cannot keep their herds apart during disease outbreaks, thereby spreading diseases more rapidly. The Bodi also experienced difficulty getting veterinary care. This difficulty is partly a product of the hostile relationship between the Bodi and the local government

\footnotetext{
${ }^{24} \mathrm{FGD}$ with women, Hana, 6 August 2018.

${ }^{25}$ FGD with elders, Hana Villagisation site, 5 August 2018; FGD young men, Salamago, 6 August 2018; Interview: Salamago district expert, with long experience, 3 August 2018.

${ }^{26}$ FGD with elders, Hana Villagisation site, 5 August 2018; FGD young men, Salamago, 6 August 2018; FGD with women, Hana, 6 August 2018; Interview: Salamago district expert, with long experience, Hana, 3 August 2018.
}

veterinarians and partially due to the general insecurity in the area. Insecurity means that the district veterinarians fear venturing beyond the outskirts of Hana town, and hence, they fail to provide the services to the herds.

Bodi pastoralists list the high disease burden and the lack of care by the public veterinarians as among the most important drivers of cattle sales. ${ }^{27}$ In the words of one informant, the rush is to 'sell an animal at early stages of getting sick, before it gets too weak or sick and before its price falls. In addition to avoiding a complete loss, the individual will also have some money to buy veterinary drugs to save the remaining animals in the herd'. ${ }^{28}$ The Bodi herd is mainly composed of cattle, and the main buyers (restaurants and canteens serving the labour force working in the sugar sector) prefer to buy cattle over goats. The money a Bodi man makes from selling a cattle usually adequately covers the needs behind the sale, ${ }^{29}$ especially maize and veterinary drugs. Some sell a big animal and, after making the necessary expenses, are still able to buy a calf or heifer with the remainder..$^{30}$ Informants highlighted that, as there is not a prominent saving culture among young Bodi males, any remaining cash is used to drink with friends in town. A large number of traders-predominately female-have met this demand and supply various alcoholic drinks near to the markets. ${ }^{31}$ As such and in contrast to many stereotypes, young men do not sell animals to buy alcohol: rather surplus money is used for this end. As even female respondents stress, 'no man sells his cattle with the purpose of drinking. ${ }^{32}$

Despite the above reasons that explain the market engagement of the Bodi, discussions with government officials both at district and zonal levels show that they share a standard view of Bodi's market averse behaviour. Officials recognize the increasing trend towards market engagement, ${ }^{33}$ but they assess this engagement as limited compared to the Bodi's herd. Moreover, the Bodi

\footnotetext{
${ }^{27}$ Interview: Salamago district expert, with long experience, 3 August 2018.

${ }^{28}$ On average, an ox fetches 5,000 to 7,000 Birr (112 to 157 USD), while a 100-kg maize and veterinary care will be less than a thousand Birr (22 USD). As much as 2000 Birr (44 USD) might be sent to an imprisoned man, and a conjugal visit might cost about 5,000 Birr (112 USD) (including money to be given to the prisoner).

${ }^{29}$ Various interviews and informal discussions.

${ }^{30}$ FGD young men, Salamago, 6 August 2018; FGD with women, Salamago, 6 August 2018.

${ }^{31}$ FGD with women, Salamago, 6 August 2018.

${ }^{32}$ At the time of fieldwork, on the weekly market day (Saturday), the town gets between 1500 and 2000 Birr (US\$51.75 to US\$69) in the form of taxes and fees from the sale of about 150 animals (approximated by the full utilization of one receipt book with 150 leaves per market day). Interview, expert, Salamago Woreda, Revenue Office, 4 August 2018. Interviews, Municipality Officers, 28 July 2018.

${ }^{33}$ Interviews: Pastoral Affairs Bureau, South Omo Zone, 25 July 2018; Trade Bureau, Salamago Woreda, 3 August 2018; zone senior security official, 9 July 2018.
} 
are accused of spending money on alcoholic drinks, which, officials say, leads to anti-social behaviour. The Bodi's purchases of food and non-food commodities, including veterinary medicines, do not appear to be recognized by district and zone officials, who focus solely on the perceived increase in alcohol consumption in the area. $^{34}$

\section{Distress selling of livestock and impoverishment}

Salamago's economy is rapidly becoming monetized. In less than a decade, the Bodi have been coerced to increase their reliance on selling cattle to meet their most basic needs. This increasing market engagement is not benefitting any section of the Bodi, ${ }^{35}$ as is the case in other pastoral communities, such as the Somali and the Borana, where wealthier groups gain (see Aklilu and Catley 2014; Aklilu and Catley 2010a; Aklilu and Catley 2010b; Aklilu and Catley 2010c). As indicated in the previous section, most of the pressing needs leading the Bodi into livestock marketing are related to insecurity and other implications of 'development'.

The 'development' interventions and the accompanying insecurity in Bodi territory created and deepened food insecurity. Imprisonment of large numbers of men not only limited human capital at the household level but also disturbed the culturally sanctioned birth cycle, which was resolved by women (until 2016 only) who expended large sums of money for unofficial 'conjugal visits'. On top of this, higher drinking behaviour of the Bodi, associated with higher availability of cash following sale of animals, gave further justification for their continued marginalization and the unwillingness of district experts to provide veterinary care to the Bodi herd. These combined pressures are leading to a deterioration of livelihoods and erosion of food security.

This is not the first case in Ethiopia's pastoral area of 'development' becoming the opposite of what was intended, at least for local communities. Policies designed to 'modernize' and 'improve' the lives of pastoralists may end up unleashing a political economy of dispossession, particularly the privatization of land and water (Ashami 2018; Lind et al. 2020). Limiting or completely preventing access to these key resources for pastoral production systems inevitably results in deepening poverty and deterioration of welfare for affected groups. In Salamago, we have

\footnotetext{
${ }^{34}$ Unlike the experience of the Somali and Borana pastoralists, in Bodi's case, there is no group of (younger) men who take advantage of poorer households by buying from them and selling at a profit after some weeks. Neither is there an increase in inequality among the Bodi which is linked to market engagements. On top of that, there is no group which is taking up livestock trading as a new livelihood component (see Gebresenbet 2020).

${ }^{35}$ FGD with elders, Hana villagisation site, 5 August 2018; FGD with young men, Salamago, 6 August 2018.
}

the added element of insecurity. The large-scale imprisonment of men added a non-material, cultural dimension to the equation, which brought more pressure upon households to sell their livestock.

The viability of flood-retreat and rain-fed farming to meet food security needs was severely diminished by the Gibe III dam and insecurity. Irrigated farming as an alternative is available only to those who can access land near to the irrigation canals. Thus, the majority of the Bodi households who initially joined the newly established villages-voluntary or under pressure-eventually abandoned these sites. Even if irrigation water is available, the removal of shade trees makes farming difficult in the heat and direct sun (Buffavand 2017). In addition, village sites are already being abandoned, as the benefits/social services promised by the government are not delivered (Gebresenbet 2021). The yield from rain-fed farming generated a third of the annual diet for Bodi households before the 2000s, but to meaningfully pursue this livelihood, the imprisoned men would need to be freed to provide the required labour. Peace would also need to be reached with the Konso. However, even if these conditions were met, rain-fed farming on a smaller land area (as the Konso settlement already took significant parts) would not be adequate to ensure local food security.

Under these restrictive conditions, the agency of the Bodi is mainly expressed in their decisions and actions to meet food security needs and (for a brief period between 2012 and 2016) maintain the cultural 'birth cycle' by selling from their herd. But this is not the only strategy in their basket. Although limited, rain-fed and irrigated farming is practised by some, while others have opted to do mundane wage labour for the sugar corporation. The mundane nature of the jobs given to the Bodi-men as watchmen and women weeding fieldsare interpreted as a government tactic to buy their compliance (Buffavand 2021; LaTsoky 2021). Bodi informants also stress that those working for the sugar corporation were able to better withstand food insecurity, thanks to a regular income, however small. ${ }^{36}$ The small wages from regular employment can at least complement other means of livelihoods and, in some cases, enable households to buy calves or heifers to restock. ${ }^{37}$ However, if the experience in lower Omo is like that in East Shoa, where the sugar corporation pushed smallholders into cooperatives but wages did not cover rising food expenses, then prospects for Bodi seeking to engage look bleak (Lavers 2012).

Therefore, it is very likely that the Bodi will continue to combine various strategies to meet their subsistence requirements and also to meet their cultural requirements. Distress selling of livestock, leading the Bodi into

\footnotetext{
${ }^{36}$ Ibid.

${ }^{37}$ Various interviews and observation.
} 
collective impoverishment, appears to dominate among the available options. This trend of impoverishment at the community level is already felt by Bodi informants, while the extent of this pattern will likely increase if the socio-economic and political pressures-including insecurity-do not improve in the near future.

\section{Conclusion and policy recommendations}

Past studies about livestock marketization in pastoral areas of Ethiopia and the Horn of Africa focused primarily on territories which had been integrated into national and regional livestock value chains for decades. This article focused on Ethiopia's south-western frontier, Salamago district of the lower Omo valley, which experienced little monetized livestock marketing before the 2010s, and examined the implications of aggressive state development interventions on livestock marketing behaviours of the Bodi agro-pastoral group. State intervention-expressed mainly in the form of dam-building, the establishment of sugar estates, the resettlement of hundreds of foodinsecure households and the security-oriented approach to protect state interests-did not bring the stated outcome of improving the lives of the Bodi. Rather than benefitting from these 'development' interventions, the Bodi witnessed a permanent deterioration of their food security and experienced deepening insecurity and imprisonment of a large number of their young men.

The systemic pressure resulting from diminished resources, a heavy-handed government security campaign, the imprisonment of many men and the disturbance of the culturally-sanctioned birth cycle pressurized the Bodi to sell cattle. Distress selling of livestock has become necessary to buy food for physical survival, as well as to maintain their social fabric and ethos, i.e. to maintain the herd in the face of cattle diseases and to keep birth cycles through 'conjugal visits' to imprisoned husbands. In effect, the increasing market engagement does not reflect the success of the 'modernizing' visions of eradicating agro-pastoralists 'market averse' behaviour. With the deterioration of other livelihood strategies and the limited opportunities to get employed in the modern sector, excessive reliance on selling livestock became the most viable strategy.

It is unlikely that this strategy will remain viable for the longer term. Policies aimed at extricating the Bodi from this situation will mainly have to improve the local security situation, particularly addressing their relationship with the state. Redressing the inimical relationship with the state will enable the Bodi to have secure and safe access to rain-fed farming sites in mid-altitude areas, get veterinary care for their herds and possibly lead to the release of the many imprisoned men. This could improve the viability of other strategies and forestall the total herd loss of the Bodi.

\section{Abbreviations}

CSA: Central Statistical Agency; ESC: Ethiopian Sugar Corporation; FGD: Focus group discussion; GCAO: Government Communication Affairs Office; MoFED: Ministry of Finance and Economic Development; SEPDM: Southern Ethiopia People's Democratic Movement; SNNP: Southern Nations, Nationalities and Peoples regional state; WG: Wealth Group

\section{Acknowledgements \\ I acknowledge the assistance of Jeremy Lind, Ian Scoones and Andy Catley in different stages of the research.}

\section{Author's contributions}

The author read and approved the final manuscript.

\section{Funding}

The author acknowledges the financial support from Carnegie Center through the Africa Peacebuilding Network of the Social Science Research Council, which enabled fieldwork in 2017 on development and conflict dynamics in South Omo. The 2018 fieldwork tailored to market engagement was possible by funding from the Agricultural Policy Research in Africa (APRA) project of the Institute of Development Studies.

Availability of data and materials

The datasets used and/or analysed during the current study are available from the corresponding author on reasonable request.

\section{Declarations}

Ethics approval and consent to participate

Not applicable.

\section{Consent for publication}

Not applicable.

\section{Competing interests}

The author declares that there are no competing interests.

Received: 27 May 2020 Accepted: 10 September 2020

Published online: 24 November 2021

\section{References}

Abbink, Jon, et al. 2014. Lands of the Future: Transforming Pastoral Lands and Livelihoods in Eastern Africa. Max Planck Institute for Social Anthropology Working Paper 154. Halle (Saale): Max Planck Institute for Social Anthropology. Retrieved 12 August 2018 from http://www.eth.mpg.de/cms/ de/publications/working_papers/wp0154

Aklilu, Y., and A. Catley. 2010a. Livestock Exports from the Horn of Africa: An Analysis of Benefits by Pastoralist Wealth Group and Policy Implications. Medford: Feinstein International Center, Tufts University.

Aklilu, Y., and A. Catley. 2010b. Mind the Gap: Commercialization, Livelihoods and Wealth Disparity in Pastoralist Areas of Ethiopia. Medford: Feinstein International Center, Tufts University.

Aklilu, Y., and A. Catley. 2010c. Livestock Exports from Pastoralist Areas: An Analysis of Benefits by Wealth Group and Policy Implications, IGAD LPI Working Paper 01-10. Medford: Feinstein International Center, Tufts University.

Aklilu, Y., and A. Catley. 2014. Pastoral Livestock Trade and Growth in Ethiopia, Future Agricultures Policy Brief, 72. Brighton: Future Agricultures.

Asfaw, A. 2005. Challenges and Opportunities of 'Salamago Resettlement'. The Resettlement of Konso Farmers in the Ethnic Land of the Bodi AgroPastoralists, South-West Ethiopia. Addis Ababa: Forum for Social Studies.

Ashami, Maknun G. 2018. The Political Economy of the Afar Region of Ethiopia: A Dynamic Periphery. (Original: Cambridge 1985; Reprin:MPI: 2018). MPI Field Notes and Research Projects XXII. Max Planck Institute for Social Anthropology, Halle (Saale), Germany. Retrieved from https://www.eth.mpg. de/5242605/FN_Vol22_PoliticalEconomyAfarRegion_web.pdf.

Barrett, C. B., Bellemare, M. F., \& Osterloh, S. M. 2006. Household-level livestockmarketing behavior among Northern Kenyan and Southern Ethiopian pastoralists: Research and Policy Challenges. In J. McPeak, \& P. D. Little (Eds.), Pastoral Livestock Marketing in Eastern Africa: Research and Policy Challenges (pp. 15-38). ITDG Publishing. http://www.nber.org/cha pters/c12819.pdf 
Batterbury, S.P.J., and F. Ndi. 2018. Land Grabbing in Africa. In The Routledge Handbook of African Development, ed. J.A. Binns, K. Lynch, and E. Nel, 573582. London: Routledge.

Behnke, R. and Kerven, C. 2013. Counting the Costs: Replacing Pastoralism with Irrigated Agriculture in the Awash Valley, North-eastern Ethiopia. IIED Climate Change Working Paper No. 4 (March 2013). London: International Institute for Environment and Development. Retrieved from https://pubs.iied.org/sites/ default/files/pdfs/migrate/10035IIED.pdf.

Bogale, A., M. Tamirat, and D. Alemu. 2014. Empirical Investigation of Pastoralists' Behaviour towards Participation in the Cattle Market in Omo Valley of Southern Ethiopia. The Journal of Developing Areas 48 (1): 127-143.

Bridge, G. 2001. Resource Triumphalism: Postindustrial Narratives of Primary Commodity Production. Environment and Planning A 33 (12): 2149-2173.

Buffavand, L. 2017. Vanishing Stones and the Hovering Giraffe: Identity, Land and the Divine in Mela, South-West Ethiopia. PhD Dissertation, Integration and Conflict Department, Max Planck Institute for Social Anthropology, Germany.

Buffavand, L. 2021. State-Building in the Ethiopian South-western Lowlands: Experiencing the Brunt of State Power in Mela. In: Lands of the Future-Future of the Lands: Anthropological Perspectives on Agro-pastoralist, Investment and Land Use edited by Gabbert, C. E., F. Gebresenbet, J. Galaty and G. Schlee. New York: Berghahn. Pp. 405-434.

Central Statistical Agency. 2008. Summary and Statistical Report of the 2007 Population and Housing Census: Population Size by Age and Sex. Addis Ababa: Central Statistical Agency of Ethiopia.

Davis, K.F., P. D'Odorico, and M.C. Rulli. 2014. Land Grabbing: A Preliminary Quantification of Economic Impacts on Rural Livelihoods. Population and Environment 36: 180-192.

Eid, A. 2014. Jostling for Trade: The Politics of Livestock Marketing on the Ethiopia-Somaliland Border. Future Agricultures Working Paper 75, Institute of Development Studies, University of Sussex, Brighton. Retrieved from https://assets.publishing.service.gov.uk/media/57a089c6ed915d3cfd00040e/ FAC_Working_Paper_075.pdf.

Ethiopian Sugar Corporation (ESC). 2018. Omo-Kuraz Sugar Development Project. Project details from official website ofthe ESC. Retrieved from https://etsugar. com/projects/omo-kuraz-sugar-development-project-2/.

Fukui, K. 2001. Socio-political Characteristics of Pastoral Nomadism: Flexibility among the Bodi (Mela-Me'en) in Southwest Ethiopia. Nilo-Ethiopian Studies 7: 1-21.

Gabbert, E.C. 2021. Introduction - Lands of the Future: Futuremaking with Pastoralists. In Lands of the Future-Future of the Lands: Anthropological Perspectives on Agro-pastoralist, Investment and Land Use, ed. C.E. Gabbert, F. Gebresenbet, J. Galaty, and G. Schlee, 1-65. New York: Berghahn.

Gebresenbet, F. 2020. Divergent Terms of Market Integration of Agro-Pastoralists: Marketisation and Distress Selling of Livestock in South Omo, Ethiopia. APRA working paper 27, Future Agricultures Consortium. Institute of Development Studies, University of Sussex, Brighton.

Gebresenbet, F. 2021. Villagisation in Ethiopia's Lowlands: Development vs. Facilitating Control and Dispossession. In: Lands of the Future-Future of the Lands: Anthropological Perspectives on Agro-pastoralist, Investment and Land Use edited by Gabbert, C. E., F. Gebresenbet, J. Galaty and G. Schlee. New York: Berghahn. Pp. 344-373

Government Communications Affairs Office (of Ethiopia; GCAO). 2015. The Ethiopian Human Rights Landscape in the Context of Right-Based Approach to Development. Retrieved on 25 September 2015 from http://www.gcao.gov.et/ documents/10157/107515/The+Ethiopian+Human+Rights+Landscape++in+ the+Context+of+Right-Based+Approach

Kamski, B. 2016. The Kuraz Sugar Development Project (KSDP): Between 'Sweet Vision' and Mounting Challenges. Journal of Eastern African Studies 10 (3): 568-580.

Kefale, A., and F. Gebresenbet. 2014. The Expansion of the Sugar Industry in the Southern Pastoral Lowlands. In Reflections on Development in Ethiopia: New Trends, Sustainability and Challenges, ed. D. Rahmato, M. Ayenew, A. Kefale, and B. Habermann. Addis Ababa: Forum for Social Studies and Friedrich Ebert Stiftung.

LaTsoky, S. 2021. Customary Land Use and Local Consent Practices in Mun (Mursi): A New Call for Meaningful FPIC Standards in Southern Ethiopia. In: Lands of the Future-Future of the Lands: Anthropological Perspectives on Agropastoralist, Investment and Land Use edited by Gabbert, C. E., F. Gebresenbet, J. Galaty and G. Schlee. New York: Berghahn. Pp. 435-479.

Lavers, Tom. 2012. Patterns of Agrarian Transformation in Ethiopia: StateMediated Commercialisation and the 'Land Grab.'. Journal of Peasant Studies 39 (3-4): 795-822
Lind, Jeremy, D. Okenwa, and I. Scoones. 2020. Land, Investment and Politics: Reconfiguring East Africa's Pastoral Drylands. Oxford: James Currey.

Markakis, J. 2011. Ethiopia: The Last Two Frontiers. Oxford: James Currey.

Matondi, P., K. Havnevik, and A. Beyene. 2011. Biofuels, Land Grabbing and Food Security in Africa. London/New York: Zed Books.

Ministry of Finance and Economic Development (MoFED). 2010. Growth and Transformation Plan (2010/11-2014/15). Volume I: MainText. MoFED, Federal Democratic Republic of Ethiopia. Addis Ababa.

Mosley, J., and E. Watson. 2016. Frontier Transformations: Development Visions, Spaces and Processes in Northern Kenya and Southern Ethiopia. Journal of Eastern African Studies 10 (3): 452-475.

Schareika, N. 2018. Nomads/Pastoralists and Development. In The International Encyclopedia of Anthropology, ed. H. Callan. Hoboken and Chichester: Wiley Blackwell. https://doi.org/10.1002/9781118924396.wbiea1611.

Schlee, G. 2010. A Comment on the "Policy Framework for Pastoralism in Africa" Adopted by the African Union in January 2011. Nomadic Peoples 14 (2): 158163.

Scott, J.C. 2009. The Art of Not Being Governed: An Anarchist History of Upland Southeast Asia. New Haven: Yale University Press.

SEPDM (Southern Ethiopia People's Democratic Movement). 2010. Public Relations Plan for the Sugarcane Development Plan on the Omo River. Zone branch of the SEPDM. Jinka (July, 2010).

Stevenson, E.G.J., and L. Buffavand. 2018. 'Do Our Bodies Know Their Ways?' Villagization, Food Insecurity, and III-Being in Ethiopia's Lower Omo Valley. African Studies Review. https://doi.org/10.1017/asr.2017.100.

Stevenson, J. 2018. Plantation Development in the Turkana Basin: The Making of a New Desert? Land 7 (1). https://doi.org/10.3390/land7010016.

Turton, D. 2021. Breaking Every Rule in the Book: The Story of River Basin Development in Ethiopia's Omo Valley. In: Lands of the Future-Future of the Lands: Anthropological Perspectives on Agro-pastoralist, Investment and Land Use edited by Gabbert, C. E., F. Gebresenbet, J. Galaty and G. Schlee. New York: Berghahn. p. 375-404.

Vincent, Nge'no; Korir, M.K.; Nyangweso, P.M.; Kipsat, M.J; and Lagat, B.K. 2010. Pastoralists Non-Responsiveness to Livestock Markets in East Pokot, Kenya. Poster presented at the Joint 3rd African Association of Agricultural Economists (AAAE) and $48^{\text {th }}$ Agricultural Economists Association of South Africa (AEASA) Conference, Cape Town, South Africa, September 19-23, 2010.

Woldemariam, T., and F. Gebresenbet. 2014. Socio-political and Conflict Implications of Sugar Development in Salamago Wereda, Ethiopia. In A Delicate Balance: Land Use, Minority Rights and Social Stability in the Horn of Africa, ed. M. Gebrehiwot, 117-143. Addis Ababa: Institute for Peace and Security Studies, Addis Ababa University.

Zenawi, Meles. 2011. Speech during the $13^{\text {th }}$ Annual Pastoralist Day Celebrations, Jinka, South Omo. Retrieved on 22 January 2019 from http://www.mursi.org/ pdf/Meles\%20Jinka\%20speech.pdf.

\section{Publisher's Note}

Springer Nature remains neutral with regard to jurisdictional claims in published maps and institutional affiliations.

\section{Submit your manuscript to a SpringerOpen ${ }^{\circ}$ journal and benefit from:}

- Convenient online submission

- Rigorous peer review

- Open access: articles freely available online

- High visibility within the field

- Retaining the copyright to your article

Submit your next manuscript at $>$ springeropen.com 